\title{
Swath Grazing Forage Sorghum and Pearl Millet Observations Regarding Quality and Utilization as Winter Feed
}

\section{DOI:10.31274/air.12602}

\author{
Garland Dahlke, Iowa Beef Center; \\ David Bruene, Beef Teaching Herd Superintendent, \\ Iowa State University
}

\section{Summary and Implications}

Swath grazing provides a viable winter feed option for beef cows in Iowa.

\section{Introduction}

Swath grazing is a strategy to provide winter feed to beef cows and replacements where snow depth can challenge the winter management of the cow herd. Although it has been used in Canada and in some parts of the Western US for some time, it has been slow to gain acceptance in the upper Midwest and Eastern US. In Iowa, this practice is fairly rare currently, but does seem to work for those who implement this practice, including the Iowa State University Beef Teaching Farm's herd (ISU). This strategy, although used has not had much data collected up to this time. The purpose of this paper is to address the details of forage quality, and utilization as observed with the campus farm.

This strategy has some challenges in that it will require a good perimeter fence, water availability and land that allows access to mowing and raking equipment. The reasons for considering this strategy over others in providing winter cow feed were as follows:

1.To better handle time constraints in the fall when other tasks also needed to be done.

2.To reduce extra harvest costs involved in baling, hauling and then later feeding bales.

3. Since drying weather for dry hay production in the fall is not guaranteed, the cost of wrapping bales is eliminated.

4. Pen yardage, bedding and manure distribution from winter feeding should not be an issue.

5. Utilization of forage over other forms of grazing, such as stockpile grazing, should be theoretically better in the case of substantial snow cover.

6.The field should be relatively unharmed from feeding and dead areas from bale leftovers should not be an issue if the cows are given adequate time to consume the forage provided in the swaths.
Materials and Methods

Two fields, about 36 total acres, which had been seeded earlier in the year with pearl millet and forage sorghum were use in this project along with the ISU spring calving, 80 head, beef cow herd. The millet and sorghum were harvested once in late July as a hay crop and then allowed to regrow undisturbed until the final cutting taken in early December just prior to the first predicted substantial snow fall of the year. Fields were mowed December 6, raked December 9 and covered with snow December 11. Cows, bred to start calving in March, were moved from corn stalk residue to the swaths December 23. The swaths were about 2 feet wide and about 9 inches high in this year.

Forage nutrient content was measured October 16 (after first killing frost, December 9, January 5 and February 1 from the ungrazed windrows. A final sampling of the residual forage was taken after the cows had grazed and snow subsided on March 8. All forage samples were submitted to Rock River Laboratory, Watertown WI. NIR was used in the analysis, however the ash content in the residual forage was too high for the NIR calibration and required a wet chemical analysis.

Forage yield in the swaths was measured December 9, after raking. Residual forage after grazing was measured during times when snow had subsided (January 9 and March 8). Three-foot sections of the window were sampled across the field and the distance between windrows was measured at these selected points to determine weight of forage in the area for the yield data.

Cow were given access to three days of grazing / feed and then the fence was moved for another three days allotment. This intake allotment estimate was based on the initial dry matter yield calculations taken in December and allowing 30 pounds of dry matter intake per head per day. Gallagher Tumble wheel fence posts were used as a movable fence. The break wire ran perpendicular to the swaths. Cows were provided the swaths as their only feed, apart from mineral and vitamin supplementation, through mid-February when the swathed forage was depleted. At this time, they were three weeks from the beginning of calving and were provided with a corn silage based TMR

\section{Results and Discussion}

Weather during the time of this trial contained a series of freeze, snow, rain and thaw events from December through January. Snow cover during this time ranged from zero to three inches then in the second half of January increased to 12 inches which persisted through the mid-

Copyright (C) 2021 by the Authors. This is an open access article published under the CC BY-NC license (https://creativecommons.org/licenses/by-nc/4.0/), which allows for non-commercial reuse with proper attribution. 
February when the cows completed the swath grazing. Temperatures were seasonal but became consistently below zero Fahrenheit during the first two weeks of February reaching minus 20 for a number of days in this stretch of time.

Forage quality data is provided in Table 1. Quality does drop over time and the series of freeze-thaw and moisture events may be a big factor in the extent of this drop. Cutting this material in mid-summer as hay and then using the regrowth for swath grazing seems to have a big influence in raising the initial quality of this forage for swath grazing. The leaching of nutrients occurred in the standing crop from the time of the first killing frost until cutting, but the quality was still more than adequate for the cows as they began their third trimester of pregnancy. Over time, the quality would have probably would have been better maintained in the cut material if the weather would have been consistently cold with no rain. It was because of this potential for wet weather that the forage was cut as late as possible. The material that was not consumed appeared to be quite rank and testing confirmed this observation, thus the quality of the material consumed by the cows was apparently considerably better than what was determined as the average forage quality from our samples. The use of cool season grasses may also aid in providing or maintaining higher quality feed during this time and may merit future trials.

Yield data is provided in Table 2. Dry weather after the initial cutting in July limited yields substantially. It was estimated that dry matter yield was about half from what would have normally been expected. Utilization rates of this forage are provided in Table 2. It was very encouraging that our utilization rate hovered around $70 \%$ throughout the time of the trial regardless of snow depth and ice crusting.

The nutrient value of this feed declined over the time of the study. By the end of our trial in mid-February the quality was probably inadequate for cows in their last month of their pregnancy. It was at this time though that the cows were switched to their last gestation TMR and no adverse situations such as weak calf syndrome were encountered. It did appear, from the residual forage that was analyzed, that the cows selected the best of the forage and left the coarse stems thus eating "better" than the forage analysis would indicate.

There were no real drawbacks noticed in this feeding strategy other than the challenges mentioned in the introduction. The following indicates some of the positive aspects that were observed:

1. Utilization of forage did not change with snow accumulations up to 12 inches in depth.

2. Mud and unfroze ground during the thaw periods did not cause noticeable damage to field while cows were grazing.

3. Cows stayed clean and hair coats seemed to be in good condition throughout the trial. The February temperatures which dropped to 20 degrees below zero Fahrenheit did not seem to affect the cows in their grazing activity or health.

4. Cow behavior in terms of cows moving and being manageable from a temperament standpoint was similar to cows managed with intensive grazing in that they were very responsive in cooperating with the herdsman to grazing movements.

5. There is no manure to haul, ruts to fill in or need to run equipment during the time of swath grazing.

6. Fall labor requirements are more manageable since hay harvest is not necessary at this time.

7. Daily labor is reduced substantially in the winter since cows were moved once every three days rather than having to feed them every day.

8. Although forage utilization was $70 \%$ and forage utilization may be close to $85 \%$ if harvested forage was fed daily to cows, the cost savings from not having to harvest and move bales was still more cost effective with swath grazing.

9. The utilization of forage in swath grazing, especially after a snowfall, makes this system more cost effective than stockpile grazing even when swathing and raking are considered.

10. Grazing residue was minimal and would not inhibit regrowth a perennial forage crop if the swath grazing would have occurred on a hay field or permanent pasture.

\section{Acknowledgements}

This project was made possible through a mini grant from the Iowa Beef Center and cooperation from the Iowa State University Beef Teaching Farm. 
Table 1. Nutrient content of feed over time

\begin{tabular}{|l|l|l|l|l|l|l|l|}
\hline Crop & Date & Dry Matter & Cr.Protein & TTNDFd & NE m & NFC & Ash \\
\hline Sorghum & Oct 16* & 30.7 & 19.64 & 52.4 & 0.60 & 18.0 & 11.0 \\
\hline & Dec 9 & 80.0 & 10.4 & 42.0 & 0.34 & 15.6 & 12.5 \\
\hline & Jan 5 & 44.7 & 11.7 & 20.5 & 0.10 & 12.4 & 20.9 \\
\hline & & & & & & \\
\hline Millet & Oct 16* & 24.3 & 14.1 & 51.0 & 0.48 & 16.3 & 12.7 \\
\hline & Dec 9 & 81.4 & 12.9 & 42.7 & 0.40 & 16.0 & 11.1 \\
\hline & Jan 5 & 37.2 & 9.7 & 18.8 & 0.14 & 16.2 & 19.8 \\
\hline & Feb 1 & 37.2 & 13.6 & 33.2 & 0.3 & 15.3 & 12.3 \\
\hline & $\begin{array}{l}\text { Refusals } \\
\text { (March 8) }\end{array}$ & 54 & 7.5 & - & $<0.1$ & 0 & 26.7 \\
\hline
\end{tabular}

*Analysis taken after first killing frost

TTNDFd = total tract neutral detergent fiber digestibility

$\mathrm{NEm}=$ megacalories per pound dry matter of net energy -maintenance

Table 2. Forage yield and utilization

\begin{tabular}{|l|l|l|l|l|}
\hline & Tons DM / Acre & $\begin{array}{l}\text { Tons Waste } \\
\text { DM/Acre }\end{array}$ & \% Utilization & Notes \\
\hline Sorghum & 1.42 & 0.44 & 69.3 & $\begin{array}{l}3 \text { inches of snow } \\
\text { cover }\end{array}$ \\
\hline Millet \#1 & 1.41 & 0.38 & 72.9 & $\begin{array}{l}3 \text { inches of snow } \\
\text { cover }\end{array}$ \\
\hline Millet \#2 & 2.01 & 0.59 & 70.5 & $\begin{array}{l}12 \text { inches of snow } \\
\text { cover }\end{array}$ \\
\hline
\end{tabular}

